\title{
Exercise and Training at Altitudes: Physiological Effects and Protocols
}

Ejercicio y entrenamiento en altura: efectos fisiológicos y protocolos

Exercício e treinamento em altura: efeitos fisiológicos e protocolos

Olga Cecilia Vargas Pinilla, Ft, MSc.'

Recibido: 17 de junio de $2013 \bullet$ Aceptado: 19 de noviembre de 2013

Doi: dx.doi.org/10.12804/revsalud12.1.2014.07

Para citar este artículo: Vargas-Pinilla OC. Exercise and Training at Altitudes: Physiological Effects and Protocols. Rev Cienc Salud. 2014;12(1):107-122. doi: dx.doi.org/10.12804/revsalud12.1.2014.07

\begin{abstract}
An increase in altitude leads to a proportional fall in the barometric pressure, and a decrease in atmospheric oxygen pressure, producing hypobaric hypoxia that affects, in different degrees, all body organs, systems and functions. The chronically reduced partial pressure of oxygen causes that individuals adapt and adjust to physiological stress. These adaptations are modulated by many factors, including the degree of hypoxia related to altitude, time of exposure, exercise intensity and individual conditions. It has been established that exposure to high altitude is an environmental stressor that elicits a response that contributes to many adjustments and adaptations that influence exercise capacity and endurance performance. These adaptations include increase in hemoglobin concentration, ventilation, capillary density and tissue myoglobin concentration. However, a negative effect in strength and power is related to a decrease in muscle fiber size and body mass due to the decrease in the training intensity. Many researches aim at establishing how training or living at high altitudes affects performance in athletes. Training methods, such as living in high altitudes-training low, and training high-living in low altitudes have been used to research the changes in the physical condition in athletes and how the physiological adaptations to hypoxia can enhance performance at sea level. This review analyzes the literature related to altitude training focused on how physiological adaptations to hypoxic environments influence performance, and which protocols are most frequently used to train in high altitudes.
\end{abstract}

Key Words: Exercise, altitude, physiological adaptation, training, athletic performance.

1 Programa de Fisioterapia, Escuela de Medicina y Ciencias de la Salud, Universidad del Rosario. Correspondencia: olga.vargas@ urosario.edu.co 


\section{Resumen}

A mayor altitud se produce una disminución proporcional en la presión barométrica y atmosférica del oxígeno. Esto genera hipoxia hipobárica que afecta, en diferentes grados, a todos los órganos, sistemas y funciones del organismo. La reducción crónica de la presión parcial de oxígeno hace que los individuos se adapten y se ajusten a este estrés fisiológico. La intensidad de estas adaptaciones depende de factores como el grado de hipoxia relacionado con la altitud, el tiempo de exposición, la intensidad del ejercicio y las condiciones individuales.

Se ha establecido que la exposición a la altura produce una respuesta fisiológica que contribuye en muchos de los ajustes y adaptaciones que influyen la capacidad de ejercicio y de resistencia aeróbica. Estas adaptaciones incluyen aumento en la ventilación, densidad capilar y concentración de mioglobina tisular y hemoglobina. Sin embargo, hay un efecto negativo en fuerza y potencia relacionado con una disminución en la masa muscular y el tamaño de la fibra, por una menor intensidad del entrenamiento. Métodos de entrenamiento como vivir alto - entrenar bajo y entrenar alto - vivir bajo han sido desarrollados e investigados para establecer los cambios en la condición física de los atletas y cómo las adaptaciones fisiológicas a la hipoxia pueden mejorar su desempeño a nivel del mar. Esta revisión analiza la literatura relacionada con el entrenamiento en altura, centrándose en la influencia las adaptaciones fisiológicas a ambientes hipóxicos en el rendimiento y desempeño de los atletas; y cuáles son los protocolos más frecuentemente utilizados para entrenar en altura.

Palabras clave: ejercicio, altura, adaptación fisiológica, entrenamiento, rendimiento atlético.

\section{Resumo}

A maior altitude se produz uma diminuição proporcional na pressão barométrica e atmosférica do oxigeno. Isto gera hipóxia hipobárica que afeita, em diferentes graus, a todos os órgãos, sistemas e funções do organismo. A redução crônica da pressão parcial de oxigeno faz que os indivíduos se adaptem e se ajustem a este estresse fisiológico. A intensidade destas adaptações depende de fatores como o grau de hipóxia relacionado com a altitude, o tempo de exposição, a intensidade do exercício e as condições individuais.

Tem se estabelecido que a exposição à altura produz uma resposta fisiológica que contribui em muitos dos ajustes e adaptações que influem a capacidade de exercício e se resistência aeróbica. Estas adaptações incluem aumento na ventilação, densidade capilar e concentração de mioglobina tissular e hemoglobina. No entanto, existe um efeito negativo em força e potencia relacionado com uma diminuição na massa muscular e o tamanho da fibra, por uma menor intensidade do treinamento. Métodos de treinamento como viver no alto e treinar baixo têm sido desenvolvidos e pesquisados para estabelecer as mudanças na condição física dos atletas e como as adaptações fisiológicas à hipóxia podem melhorar seu desempenho à altura do mar. Esta revisão analisa a literatura relacionada com o treinamento em altura, se centrando em como as adaptações fisiológicas a ambientes hipõxicos influem no rendimento e desempenho dos atletas; e quais são os protocolos mais frequentemente utilizados para treinar em altura.

Palavras-chave: exercício, altura, adaptação fisiológica, treinamento, rendimento atlético. 


\section{Introduction}

A high altitude environment produces physiological stress in humans. The changes can occur at moderate altitude, between 2,000 and 3,000 m; and high altitude, above 3,000 $\mathrm{m}(1,2)$. The most important factors to this stress are: hypoxia, high solar radiation, low temperature, low humidity, high winds, limited nutritional base and rough terrain(2). Physiologically speaking, the most significant is hypoxia, since the others could be present in different geographical zones.

An increase in altitude leads to a proportional fall in the barometric pressure, and to a decrease in the pressure of atmospheric oxygen. This produces hypobaric hypoxia that affects, in different degrees, all body organs, systems and functions (2,3). At high altitude, the body has to develop some adaptations and changes that allows the oxygen transport system to compensate for the hypoxia in order to maintain an adequate tissue oxygen level to support metabolism(4).

The high altitude inhabitant has adapted to the hypoxic environment to improve oxygen delivery and oxygen utilization, by modifying the respiratory, cardiovascular and metabolic systems $(2,4)$. Whether this level of functional adaptations is inherited, or acquired during growth and development, is a matter of scientific interest.

The influence of genetic factors on quantitative oxygen transport has been researched. Evidence suggests the presence of different arterial-oxygen-content phenotypes among indigenous Andean, Tibetan and Ethiopian high altitude populations(5). Andean highlanders have higher hemoglobin $(\mathrm{Hb})$ concentration and percent of oxygen saturation of $\mathrm{Hb}$ than Tibetans at the same altitude. Moreover, $\mathrm{Hb}$ concentration has a significant heritability in Andean and Tibetan samples, while oxygen sat- uration of $\mathrm{Hb}$ has a significant heritability for Tibetans(6). Scheinfeld et al. found that high altitude Ethiopian residents have significantly higher $\mathrm{Hb}$ levels than low altitude residents do, and suggest that the genes and genetic variants that contribute to this adaptation are largely distinct from other high-altitude regions (7).

Andean and Himalayan natives demonstrate higher mean maximal oxygen uptake $\left(\mathrm{VO}_{2 \max }\right)$ in hypoxia, and this value decreases in smaller proportion with increasing hypox$\mathrm{ia}(8-10)$. In the respiratory system, enhanced pulmonary gas exchange efficiency and a larger pulmonary diffusion capacity have been described. These characteristics are related to smaller alveolar-arterial oxygen partial pressure difference $\left((\mathrm{A}-\mathrm{a}) \mathrm{DO}_{2}\right)$, lower pulmonary ventilation, and higher arterial $\mathrm{O}_{2}$ saturation $\left(\mathrm{SaO}_{2}\right)$ during exercise(11). Frisancho et al. evaluated rural and urban Bolivian natives, and found that non-natives acclimatised to altitude (8). They suggest that aerobic capacity at high altitude is related to both genetic factors and developmental acclimatization. However, its expression is highly mediated by environmental factors, such as occupational activity level and body composition.

The chronically reduced partial pressure of oxygen requires that individuals adapt to the physiological stress produced by exposure to high altitude and these adaptations are modulated by many factors(11). These factors include the degree of hypoxia related to altitude, time of exposure, exercise intensity and individual conditions(12). Exposure to high altitude is an environmental stressor that elicits a response that contributes to many adjustments and adaptations influencing exercise capacity and endurance performance.

There is little doubt that being born and raised at altitude leads to a series of metabolic, musculoskeletal and cardio-respiratory adapta- 
tions to environmental hypoxia that influence oxygen transport and its utilisation. Nevertheless, there is no consensus as to how these changes affect exercise capacity and physical activity of people who live and train at moderate or high altitude, it has been reasoned that exercising in hypoxia could increase the training stimulus (13). So, after exposure to altitude, performance at sea level (SL) might be improved owed to the physiological adaptations mentioned before(14).

Many researches have examined how training or living at high altitudes might affect performance in athletes. Training methods, such as living high-training high (LH-TH) and living high-training low (LH-TL), among others, have been used to elucidate the mechanisms and physiological adaptations that occur in hypoxia (15). This review analyses the literature related to altitude training focused on the physiological effects of training and living in moderate to high altitude, on how physiological adaptations to hypoxic environments influence performance; and on which are the most frequently protocols used to train in altitude.

\section{Altitude challenge}

The 1968 Olympic Games and the 1970 FIFA World Cup, both held in Mexico City, forced athletes to prepare for competition at 2,300 m above SL(16). Also, the apparent running success of native highlanders, and the increase in the training time under altitude conditions for cross-country ski racers, provoked several researches on how physiological adaptations to hypoxia could affect performance(17). Endurance athletes and their coaches observed that, in altitude, it was more difficult to perform at high speed for long time; and, compared with $\mathrm{SL}$, recovery from hard workouts required longer time. Therefore, training programs at altitude were modified from those used at SL; many athletes noted improvements in performance, but some experienced worsening on return to $\mathrm{SL}(16)$.

The lack of oxygen as a result of the ascent from SL to moderate or high altitude impairs the endurance training and performance in the athletes initially (18). As acclimatisation occurs and the athlete adapts to the hypoxic environment, performance improves due to the functional and metabolic adaptations that influence oxygen transport and its utilisation. However, it is still being debated how these adaptations leads to an increase in performance after return to $\mathrm{SL}$, and what the related physiological mechanisms could be $(13,18,19)$.

\section{Physiological effects and acclimatisation}

When exercising at altitude the body responds and adapt to two different stressors, hypoxia and exercise (20). The magnitude of the response to these stressors influence exercise capacity and performance, and this response is mediated by the altitude level and individual characteristics. Adjustments and acclimatisation to altitude involve the central nervous, endocrine, respiratory and cardiovascular systems; the blood oxygen-carrying capacity, and morphologic and functional adaptations in the skeletal muscle $(21,22)$. The acclimatisation process aims to obtain an optimal oxygen tension of the arterial blood and to secure an adequate oxygen supply to the body tissues and organs(21).

Altitude training or training in hypoxia has been used by endurance athletes motivated by the expected enhancement in aerobic and SL performance(23-25). Some of the mechanisms of altitude acclimatisation include increase in erythropoiesis, red blood cell (RBC) mass, blood $\mathrm{Hb}$ concentration and $\mathrm{VO}_{2 \max }$; at mitochondrial level, elevated muscle efficiency and 
buffering capacity, as well as improvements in the structural and biochemical properties of skeletal muscle. At tissue level, hypoxia promotes rapid oxygen sensing and consequent cellular functions $(13,23)$.

\section{Ventilation and gas exchange}

The respiratory compensation to hypoxia is an increase in minute ventilation (VE) to boost the alveolar $\mathrm{PO}_{2}$. This leads to a rise in blood $\mathrm{pH}$ as a result of lower $\mathrm{CO}_{2}$ levels that produces an excess of bicarbonate ions(17). The respiratory alkalosis generates a metabolic compensation by the kidneys, excreting bicarbonate over the next days, thus helping restoring blood $\mathrm{pH}$ normal levels(25). This compensation can be attained within 1 day at 2,200 $\mathrm{m}$ above $\mathrm{SL}$, while remaining incomplete at an altitude of $4,100 \mathrm{~m}$ or higher altitudes(21). Because of this decrease in alkaline reserve, the buffering of additional acids, such as lactic acid produced by exercise, cannot be buffered as normal(26). Therefore, high intensity performance declines earlier than at SL within the first 2-3 days at altitudes of 2,000 $\mathrm{m}$ or higher(21).

The increase in VE that occurs with hypoxia possess an additional energy cost that could inhibit the increase in the total $\mathrm{VO}_{2 \max }$. The ventilatory acclimatisation is achieved approximately by the 6th day and is characterized by a plateau in $\mathrm{VE}, \mathrm{SaO}_{2}$ and $\mathrm{PaCO}_{2}(27)$.

The lower alveolar $\mathrm{PO}_{2}$ and the increased pulmonary blood flow during exercise produce a limitation in the diffusion capacity, which leads to a decrease in $\mathrm{PaO}_{2}$ and in $\mathrm{SaO}_{2}(17,21)$. Because of their higher maximal cardiac output, this drop will be larger in endurance athletes. Wehrlin et al. found that in athletes with $\mathrm{VO}_{2 \max }$ of $66 \mathrm{ml} / \mathrm{Kg} / \mathrm{min}, \mathrm{SaO}_{2}$ it was $86 \%$ and $76 \%$ at altitudes of 800 and $2,800 \mathrm{~m}$, respectively (28). However, in untrained subjects
$\mathrm{SaO}_{2}$ was $83 \%$ at $3,050 \mathrm{~m}$ and $73 \%$ at 4,100 m.(29)

\section{Haematological parameters}

Plasma volume decreases due to water loss, related to dry environment and hyperventilation and to fluid shift from the intravascular space into the interstitial and intracellular spaces. This loss of plasma volume, and the increase in erythropoiesis and reticulocytes induced by hypoxia, cause the augmentation of total haemoglobin and the RBC mass. $(19,30)$ As a result, the oxygen-carrying capacity of the blood increases, as well as the oxygen content of arterial blood, being higher than at SL. A significant increase in the RBC mass may occur after 3 weeks at a minimum altitude of 2,100 $\mathrm{m}$, becoming more pronounced as altitude increases(31).

The main objective of altitude training is to stimulate these responses, and thus increase $\mathrm{VO}_{2 \max }$ and improve performance capacity, both at altitude and SL. The total $\mathrm{Hb}_{\text {mass }}$ is strongly related to endurance performance at SL. Cross-sectional studies demonstrate that elite athletes have approximately 35\% higher $\mathrm{Hb}_{\text {mass }}$ than the normal population. This is elevated further by $14 \%$ in athletes native to altitudes of 2,600 m(31). Some studies have reported a significant increase in total $\mathrm{Hb}_{\text {mass }}$ and/ or RBC mass by $6-9 \%$ after $3-4$ weeks of living and training at an altitude $>2,000 \mathrm{~m}(32-34)$.

Nevertheless, this increase is not enough to close the gap in total $\mathrm{Hb}_{\text {mass }}$ between elite athletes native and altitude(31). On the other hand, other studies have not shown changes in total $\mathrm{Hb}_{\text {mass }}$ but these results may be related to illness(35) during the study or training at an altitude $<2,000 \mathrm{~m},(36)$ which is considered a critical minimal altitude for a significant increase in erythropoiesis(37). 
After 48 hours at altitude the bone marrow increases its iron uptake to form $\mathrm{Hb}$ (17). Evaluation of iron levels and supplementation prior and during the stay at altitude is necessary to secure the proper activity of the bone marrow. Inhibition of complete haematological adaptation to training at altitude has been connected to lack of iron and may account for the studies that have failed to show increase in $\mathrm{Hb}$ concentration(38).

\section{Skeletal muscle}

Hypoxia has been used to induce adaptation in skeletal muscle. Exposure to hypoxia during exercise increases the metabolic stress and the cellular disturbance. These stimulus are expected to generate adaptive results in muscle tissue beyond those achieved in normoxia $(14,39)$. Nevertheless, the response is influenced by the hypoxia level and the duration and intensity of training.

The changes include an increase in the muscle buffering capacity, the myoglobin content, the mitochondrial capacity and the capillarisation(40). These contribute to increase the peripheral uptake of oxygen by the muscles and to reduce production and increase clearance of lactate. Other changes studied include enhancement in substrate usage by mobilisation of free fatty acids and the increased use of blood glucose, saving muscle glycogen $(40,41)$.

At molecular level, a transcription factor called hypoxia inducible factor-1 (HIF-1) has been identified as a critical factor in the regulation of adaptation processes in skeletal muscle tissue after training in hypoxia(42). The activation of HIF-1 leads to transcription of specific genes that activate parameters like erythropoietin (EPO), and transferrin for iron metabolism and RBC production, vascular endothelial growth factor, glycolytic enzymes -including phosphofructokinase (PFK)-, hexokinase and lactate dehydrogenase, that are important for energy metabolism; glucose transporters 1 and 3 , and monocarboxylate transporters 1 and $4-$ critical for glucose uptake and lactate metabolism by the muscles-; and carbonic anhydrase for $\mathrm{PH}$ regulation, among others $(43,44)$.

The HIF-1 mediated responses to hypoxia can explain the increase in the EPO concentration, as well as other concurrent physiological changes such as increased carbohydrate metabolism, increased ventilation, enhanced muscle buffering, and more efficient use of oxygen in the muscles(25).

In well conditioned athletes, who already have high mitochondrial enzyme activity, living and/or training in hypoxia seems to not induce further improvement. In addition, the study's results are controversial because they differ greatly in subject training state, training duration and intensity, and altitude(40). Even though some studies reported increased mitochondrial density or citrate synthase activity(44-46), others did not $(47,48)$. StrayGundersen et al. reported no change in aerobic enzyme activities after a 4 week study with runners living at 2,500 $\mathrm{m}$ and training either at low or moderate altitudes (48).

The ability of skeletal muscle to buffer $\mathrm{H}+$ is important for $\mathrm{PH}$ regulation and to compensate the reduced buffer capacity of blood caused by hyperventilation in response to a reduced $\mathrm{PO}_{2}(19,25)$. It has been proposed that an increase in muscle buffering and the attenuation in the degree of acidosis may be related to an improvement in exercise performance(49). A significant increase in muscle buffer capacity was reported in elite cross-country skiers and runners after two weeks of living and training at altitudes between 2,000 and 2,700 m(50,51). Gore et al. reported that sleeping at simulated altitude of $3,000 \mathrm{~m}$ and training at SL increased muscle buffering by about $18 \%$ in the vastus 
lateralis (52). However, Stray-Gundersen et al. did not observe any increase in the muscle buffer capacity (48).

Muscle myoglobin concentration increases only after high intensity training in hypoxia. Terrados et al. didn't find an increase in the myoglobin concentration of the vastus lateralis in cyclist who trained in a hypobaric chamber 4-5 days per week, for 3-4 weeks, and at 2,300 $\mathrm{m}$ of simulated altitude (53). However, on a later study, healthy subjects trained one leg in normoxia and the other in hypoxia. They found a larger increase in the oxidative capacity and the muscle myoglobin, as well as in endurance times in the leg trained in hypoxic conditions, than in the other trained in normoxic conditions(54). The researchers argued that training intensities in this study were greater than in the earlier work with cyclists, thus the stimulus on muscles may had been higher. Geiser et al. reported a significant increase in the muscle volume of knee-extensors and in the capillary length density in the group training at high altitudes and high intensity, they reported also an increase in the mitochondrial volume density of vastus medialis in all groups, but with the highest increase in the high altitudes, high intensity group (46).

Altitude can also be disadvantageous for the skeletal muscle. Acute exposure to hypoxia at an altitude of 4,300 m may increase glycogenolysis, glycolysis and muscle lactate production; and a reduction in muscle mass, as well as mitochondrial deterioration have been found in prolonged exposure to altitudes above 4,500 $\mathrm{m}(14,19)$. The reduction of oxygen flux from capillary to mitochondria during chronic hypoxic training might be negative to the muscle tissue due to a possibly decrease in muscle protein synthesis. In addition, a reduction in work rate associated to lower exercise intensity may cause a detraining effect in the muscle(23).
To counteract these events, it is necessary to establish a training program in which the potential hypoxia stimulus could be dissociated from the negative effects of permanent exposure to altitude(55). Therefore, modalities like training in hypoxia and remaining in normoxia the rest of the time or vice versa have been developed and investigated. These will be discussed later in this review.

\section{Blood lactate}

Acute exposure to altitude produces an exaggerated lactate response for a given workload characterized by augmented lactate accumulation in muscle and blood, and lactate release from contracting muscle(12). However, as a result of acclimatisation, the levels of maximal and submaximal blood lactate concentration decrease in comparison to $\mathrm{SL}$, with simultaneous absolute exercise intensity. This is called the lactate paradox because the decrease in lactate occurs despite the fact that $\mathrm{VO}_{2}$ does not change $(12,21)$. The evidence is inconclusive, suggesting that the response occurs at higher altitudes, and that the time of hypoxic exposure influence this response. Hoppeler et al. analysed data from 27 controlled studies of hypoxic training while subjects were under normoxic conditions for the rest of the time (23). The altitude exposure ranged from 2,300 to $5,700 \mathrm{~m}$, and training duration from 10 days to 8 weeks. There was a similar number of studies with trained an untrained subjects. They report that among all studies there were no changes in maximal end of exercise lactate, but stated that hypoxia exposure for the time of exercise sessions alone is not sufficient to induce the expected changes.

On the other hand, in a classical altitude training camp, elite rowers and runners trained between 1,500 and 2,000 $\mathrm{m}$ at higher intensities and were compared with their controls at 
SL. In both studies, no significant change of $\mathrm{VO}_{2 \max }$ was found after training, but results suggested changes in lactate metabolism. The rowers of the altitude group had lower blood lactate concentration in the post-altitude test, and the runners had a decreased blood lactate and improved performance in a submaximal test $(56,57)$.

\section{Performance}

Altitude training has been used extensively to enhance performance. However, the evidence is inconclusive in defining the magnitude of the improvement, and in which the influencing mechanisms could be. Changes in performance after hypoxia training may be associated with changes in aerobic power components; these are: $\mathrm{VO}_{2 \max x^{\prime}}$ the fraction of $\mathrm{VO}_{2 \max }$ that represents exercise intensity, and exercise economy(58). Then, changes in endurance performance may be related to changes in these components, in the physiological parameters previously discussed, and in the contribution of anaerobic power(59). Research on altitude training and its effects on performance have been focused on these aerobic power components or their physiological variables. The most popular variable studied to evaluate aerobic performance is $\mathrm{VO}_{2 \max }$ along with others like time trials, work capacity, endurance time, exercise economy, maximal power output and lactate threshold. In the anaerobic performance, peak power and peak blood lactate are the most common $(59,60)$.

Performance under hypoxic conditions after altitude training has been studied, although not as frequently as SL performance. Results of uncontrolled studies suggest that altitude acclimatisation between 1,800 and 2,300 m improves performance at altitude by 2 to $4 \%$ (40). In studies incorporating a control group, the results suggest that the living low-training high protocol (LL-TH) leads to an increase in aerobic performance in untrained subjects, as well as in peak power output and maximal aerobic power of subelite athletes when measured under hypoxic conditions $(61,63)$. By contrast, similar protocols did not find any improvement in maximal power output, endurance performance or $\mathrm{VO}_{2 \max }$. These later results might be associated with insufficient level or duration of altitude exposure $(64,65)$.

Exercise performance at SL was analysed in a recent meta-analysis that evaluated 51 studies and six protocols of natural and artificial altitude training. In these, clear enhancements in endurance power output of $1-4 \%$ in subelite athletes with natural LH-TL, and with two protocols using artificial altitude were found. In elite athletes the enhancements were clear only with natural LH-TL. They concluded that natural LH-TL provides the best protocol for enhancing endurance performance in elite and subelite athletes(59).

Recent studies evaluating HIT and LH-TL effects on SL performance did not find a significant difference in the performance improvement obtained by both, the hypoxia and the control group. The groups showed a significant increase in $\mathrm{VO}_{2 \max }$ time trial performance and mean power output, but without differences between them(62). Although in the LH-TL study the hypoxic group showed an increase in haemoglobin mass and $\mathrm{VO}_{2 \text { max' }}$ they did not improve 10 minutes-walk performance more than control group(66).

The effects of altitude training in anaerobic performance have been recently studied. The 30-s Wingate test (WANT) is an anaerobic test frequently used to evaluate peak and mean power, and time to peak. Two studies using IHT for 90-120 minutes in 10 consecutive days and altitudes between 2,500 and 4,400 m, reported a significant improvement in the anaerobic param- 
eters of the hypoxic training groups compared with control groups $(67,68)$. They suggest that this improvement may be related to an increase in the anaerobic energy release and some factors connected to $\mathrm{PH}$ regulation and lactate transportation. However, other study using an IHT protocol at moderate to high intensity training, 30 minutes, 3 days $/ 4$ weeks, and $2,750 \mathrm{~m}$, resulted in similar increases in anaerobic performance when compared to parallel SL training(69).

vO2max is a measure used to evaluate aerobic performance that depends on cardiovascular, pulmonary and muscle metabolic functions. Aerobic performance decreases as altitude increases, thus $\mathrm{VO}_{2 \max }$ may reflect the altitude and hypoxia effects in human performance(11). In untrained or slightly trained subjects, $\mathrm{VO}_{2 \max }$ decreases approximately by $10 \%$ of the SL value for every $1,000 \mathrm{~m}$ of altitudes above $1,500 \mathrm{~m}$. Whereas in elite athletes this decrease may be significant at altitudes as low as $600 \mathrm{~m}(70)$. The reduction in $\mathrm{VO}_{2 \max }$ may be related to low $\mathrm{PO}_{2^{\prime}}$ decrease in diffusion capacity in cardiac output and in peak leg blood flow(71).

Acclimatisation induces physiologic adaptations along the oxygen cascade, so vo2max and aerobic performance improves. Although these adaptations may be enhanced with altitude training, the evidence to support the effects on $\mathrm{VO}_{2 \max }$ and performance is not clear. Controlled studies using classic altitude training showed an increase in SL performance and $\mathrm{VO}_{2 \max }$ at altitudes between 1,800 and 2,700 $\mathrm{m}(32,72)$. However, other studies using the same protocol of LH-TH, did not show any improvement while training at altitudes between 1,500 and 2,300 $\mathrm{m}(57,73)$. In a meta-analysis, Bonetti et al. found that $\mathrm{VO}_{2 \max }$ increases were very likely in subelite athletes, whereas in elite athletes a reduction was possible (59). These changes were detected with the LH-TH proto- $\mathrm{col}$, with other protocols results in this regard were unclear.

\section{Training modalities}

Altitude training has been used by athletes to obtain the physiological adaptations related to acclimatisation, a fact believed to allow them to improve performance, both at altitude and at SL. There are some variables that should be taken into account when training at high altitudes because they influence the intensity of the responses: altitude level and the time spent, intensity and training type, and characteristics like previous fitness level and individual responses to hypoxia and training. Numerous modalities combine natural or artificial hypoxic environment, continued or intermittent hypoxic exposure, as well as different altitude levels. As a result, modalities like living hightraining high ( $\mathrm{Hi}-\mathrm{Hi})$, living high-training low (Hi-Lo), living low-training high (Lo-Hi) and intermittent hypoxia have been studied(59).

Classic altitude training

In classic altitude training, also known as LH$\mathrm{TH}$ or $\mathrm{Hi}-\mathrm{Hi}$, athletes live and train at moderate altitudes, any between 1,500 and 3,000 $\mathrm{m}(19,57)$. It provides two mechanisms to improve performance: The first one is related to the acclimatisation process and the adaptations in different systems, which improve oxygen transport and/or utilisation. The second is hypoxia, which acts as an additional training stimulus. Although classic altitude training has shown an increase in SL performance in well trained athletes, controlled studies including elite athletes did not find any improvement. An extensive review by Friedman et al. (19) found that in some uncontrolled studies, performance increased in elite athletes when living and training at altitudes above 2,000 m, although $\mathrm{VO}_{2 \max }$ did not increase significantly (19). They suggest that 
training for 3-4 weeks at an altitude $\geq 2,000 \mathrm{~m}$ can be used by athletes of individual endurance sports. However, training intensities should be carefully monitored and individually designed to prevent overtraining or detraining.

The absence of a clear positive effect with Hi-Hi has been attributed to insufficient altitude, inadequate lengths of time or reduced training load. In addition, the individual response to the acclimatisation process, including erythropoiesis and an initial decrease in the aerobic performance capacity, as well as a temporary performance decline after return to sea level(22) were established.

\section{Living high- Training low}

The Hi-Lo or LH-TL model combines living at high altitude with daily sojourns to lower altitudes for training. It was proposed to avoid the decrease in training power and intensities associated with training at altitude(74). By living high, the athlete benefits from the acclimatisation effects; by training low, the athlete continues with previous training intensities and prevents the detrimental effects of chronic hypoxia, such as muscular mass loss, fatigue or deteriorated aerobic performance. The method includes altitudes between 1,800 and 2,800 $\mathrm{m}$ for living and sleeping, and transporting athletes to lower altitudes $(<1,300 \mathrm{~m})$ for training(37). This method was proposed by Levine(75) and his research group. In the first study, the athletes (runners) lived at 2,500 m but trained at 1,300 $\mathrm{m}$ for 4 weeks. They increased the $\mathrm{VO}_{2 \max }$ by $4.3 \%$ and were 25 seconds faster in a $5 \mathrm{~km}$ time trial when compared with the control group(75). In a later study, the same group evaluated 39 runners(32). The athletes were assigned for a period of 4 weeks to Hi-Hi (2,800 m), Hi-Lo (2,800 and 1,250 m) and living and training low, at $150 \mathrm{~m}$ (Lo-Lo). Although both altitude groups showed an in- crease in $\mathrm{EPO}, \mathrm{RBC}$ mass and $\mathrm{VO}_{2 \text { max' }}$ only the $\mathrm{Hi}$-Lo group reduced their time in the 5,000 $\mathrm{m}$ time trial compared with the pre-values.

However, traveling every day up and down the mountain to train at low altitudes, spending one or two hours for the drive, and adapting to different weather conditions produce stress and fatigue on the athletes. Taking into account these negative effects on athletes and the increase in financial costs, new strategies have been studied(76). The HiniLo modality combines living and training at high altitudes $(2,000-3,000 \mathrm{~m})$ with training at high intensity in low altitude $(1,250 \mathrm{~m})$, two or three times per week(16). Thirteen college runners in the HiHILo protocol increased sL endurance performance and $\mathrm{VO}_{2 \max }$ in the same degree as the Hi-Lo group did(16). In other studies, elite athletes trained under HiHILo protocol improved time trial performance, $\mathrm{VO}_{2 \text { max }}, \mathrm{Hb}$ concentration and RBC mass $(77,78)$. However, Dehnert et al.(79) did not find an increase in $\mathrm{Hb}_{\text {mass' }}$ or in $\mathrm{VO}_{2 \max }$ in 11 elite triathletes training 2-week at 1,956 $\mathrm{m}$. Maybe these results are related to low dose and duration of altitude.

The Hi-Lo concept was further modified due to a technical development of devices to provide artificial altitude, avoiding the problem of traveling to the mountains. The artificial environment can be created in a building, room or tent, where hypobaric or normobaric hypoxia is obtained either by nitrogen dilution or ambient pressure decrease $(21,76)$. Subjects can sleep at night and rest during the day in hypoxia, a fact that can be equivalent to altitudes between 2,000 and 3,500 m(80). Normobaric hypoxia studies analyzed by Hahn et al(81) have shown that sleeping in simulated hypoxia of 2,650-3,000 $\mathrm{m}$ for longer than 3 weeks offer practical benefits to elite athletes. However, these benefits are not the same due not to the increased $\mathrm{Hb}_{\text {mass }}$ or $\mathrm{VO}_{2 \text { max }}$ but rather to ad- 
aptations in muscle buffer capacity and mechanical efficiency. A French multicenter study was developed to evaluate the effects of Hi-Lo combined with hypoxic rooms(80). The subjects spent 11 to 16 hours in hypoxia, 13 to 18 days, and at altitudes between 1,200 and 3,500 $\mathrm{m}$. They suggest that an altitude up to $3,000 \mathrm{~m}$, during at least 18 days and a minimum of 12 hours/day was necessary to obtain a complete acclimatisation. Moreover, they found positive changes in $\mathrm{VO}_{2 \text { max }}$ erythropoiesis and, aerobic and submaximal performance.

\section{Intermittent Hypoxic Exposure}

Shorter exposure to hypoxia has been studied for improvement of SL performance. Intermittent hypoxic exposure (IHE) is defined as an exposure to hypoxia that can be applied for few minutes or hours, and repeated over several days or weeks(76). Intermittent hypoxia at rest (IHR) consists of breathing normobaric or hypobaric hypoxic air equivalent to an altitude between 5,000 and 6,000 m, 1.5-5 h/day for 2-3 weeks(82). Because it is applied at rest and for shorter periods of time, it allows a stronger hypoxic stimulus, which is in general well tolerated(21). IHE combined with training in hypoxia is known as intermittent hypoxic training (IHT), LL-TH or Lo-Hi. In IHT athletes training under hypoxic conditions it remains at SL all the time(76).

Like the other modalities, with IHE and IHT the goal is to provide an additional stimulus that induces altitude acclimatisation to improve both altitude and SL performance. Although the time spent in hypoxia might be not enough to elicit changes, the shorter but stronger stimulus may increase EPO production, since only relative short periods of hypoxia are needed to stimulate it(38). Then, the mechanisms to improve performance may be associated with accelerated erythropoiesis, increase in $\mathrm{RBC}$ and $\mathrm{VO}_{2 \max }(76)$.

Data are equivocal regarding the effects of IHR on exercise performance. Significant improvements in endurance performance, reticulocytes count, haemoglobin and haematocrit were reported; unfortunately these studies did not include a control group $(38,83)$. In well designed control studies, the authors did not find any improvement in $\mathrm{VO}_{2 \text { max }}$ submaximal economy or peak power $(82,84)$.

Molecular adaptations at muscular level have been observed with IHT. These adaptations include an increase in mitochondrial density, capillary-fiber ratio, and fiber crosssectional area associated with the activation of HIF-1.(44) An increase in $\mathrm{VO}_{2 \text { max }}, \mathrm{VO}_{2}$ at the lactate threshold workload, work capacity, maximal workload and lactate threshold workload, was reported after IHT $(45,85,86)$. Although some studies did not find an increase in haematocrit and $\mathrm{Hb}(85,87)$, one reported a significant improvement(67).

\section{Conclusions}

High altitude produces a physiological stress in human body. People born and raised at high altitudes has adapted and developed modifications, even at genetic level. As a consequence of the lower barometric pressure, the lower alveolar $\mathrm{PO}_{2}$ and hypoxia stimulate a series of adaptations to improve the blood oxygen carrying capacity and its utilization by the tissues. These adaptations involve different systems and have been compared with those generated by exercise and training. In that sense, altitude acclimatisation and training have been used as an additional stimulus to improve performance, both at higher altitudes and at SL.

Research developed to elucidate the potential benefits and the mechanisms is extensive, but also inconclusive. Increases in serum EPO 
levels, reticulocytes count, $\mathrm{Hb}$ and $\mathrm{RBC}$ mass have been reported. In the skeletal muscle tissue, changes in structure, function and even at molecular level have been also established. Activation of HIF- 1 appears as an important factor in the transcription of specific genes related to the increase in erythropoietic responses, glucose uptake, and energy metabolism, as well as in muscle buffering capacity, lactate and $\mathrm{PH}$ regulation.

Performance is the ultimate goal of altitude acclimatisation and training. Protocols like Hi$\mathrm{Hi}, \mathrm{Hi}-\mathrm{Lo}, \mathrm{Lo}-\mathrm{Hi}$, and IHE provided with natural and artificial methods have been developed to improve aerobic and anaerobic capacity. In the literature reviewed, the evidence suggest that the Hi-Lo or LH-TL model has advantages over SL training to improve performance, associated with an increase in $\mathrm{VO}_{2 \max x^{\prime}}$ haematological parameters, power output and economy.

The differences in protocols, duration of exposure, altitude, athlete's sport, training status and intensities make it difficult to define clear results for altitude training and acclimatisation. In addition, lack of control and high quality studies constitute a challenge for the scientific community in order to develop new researches for establishing dose, intensity and frequency of the hypoxic stimulus.

\section{References}

1. 1. Bärtsch P, Saltin B, Dvorak J. Federation Internationale de Football Association. Consensus statement on playing football at different altitude. Scand J Med Sci Sports 2008;18(S1):96-9.

2. Frisancho AR. Human adaptation and accommodation. The University of Michigan Press 1993:220-22.

3. West JB. The atmosphere. In: Horbein TF, Schoene RB, eds. High Altitude: An Exploration of Human Adaptation. Lung Biology in Health and Disease. 161: 2005: p. 30-5.

4. Hurtado A. The influence of high altitude on physiology. In: Porter R, Knight J, eds. High altitude physiology: cardiac and respiratory aspects. A Ciba Foundation Symposium in honor of Professor Alberto Hurtado. Williams \& Wilkins, Baltimore, 1971: p.1-14.

5. Beall CM. Andean, Tibetan, and Ethiopian patterns of adaptation to high-altitude hypoxia. Integr Comp Biol 2006;46 (1):18-24.

6. Beall CM, Brittenham GM, Strohl KP, et al. Hemoglobin concentration of high-altitude Tibetans and Bolivian Aymara. Am J Phys Anthropol 19981;106(3):385-400.

7. Scheinfeldt LB, Soi S, Thompson S, et al. Genetic adaptation to high altitude in the Ethiopian highlands. Genome Biology 2012;13(1):R1.

8. Frisancho AR, Frisancho HG, Milotich M, et al. Developmental, genetic, and environmental components of aerobic capacity at high altitude. Am J Phys Anthropol 1995;96:431-42.

9. Ge RL, He Lun GW, Chen QH, Gen D, Kubo K, et al. Comparisons of oxygen transport between Tibetan and Han residents at moderate altitude. Wilderness Environ Med 1995;6:391-400.

10. Zhuang J, Droma T, Sutton JR, Groves BM, McCullough RE, McCullough RG, et al. Smaller alveolararterial O2 gradients in Tibetan than Han residents of Lhasa (3658 m). Respir Physiol 1996;103:75-82.

11. Brutsaert TD. Do high-altitude natives have enhanced exercise performance at altitude? Appl Physiol Nutr Metab 2008;33(3):582-92.

12. Mazzeo RS. Physiological responses to exercise at altitude: an update. Sports Med 2008;38(1):1-8.

13. Bailey DM, Davies B. Physiological implications of altitude training for endurance performance at sea level: a review. Br J Sports Med 1997;31(3):183-90. 
14. Vogt $\mathrm{M}$, Hoppeler H. Is hypoxia training good for muscles and exercise performance? Prog Cardiovasc Dis 2010;52(6):525-33.

15. Hoffman J. Physiological aspects of sport training and performance. Human kinetics 2002:247-58.

16. Stray-Gundersen J, Levine BD. Live high, train low at natural altitude. Scand J Med Sci Sports 2008;18(S1):21-8.

17. Drust B, Waterhouse J. Exercise at Altitude. Scott Med J 2010;55(2):31-4.

18. Wolski LA, McKenzie DC, Wenger HA. Altitude training for improvements in sea level performance. Is there scientific evidence of benefit? Sports Med 1996;22:251-63.

19. Friedmann-Bette B. Classical altitude training. Scand J Med Sci Sports 2008;18(S1):11-20.

20. Calbet JA, Lundby C. Air to muscle $\mathrm{O}_{2}$ delivery during exercise at altitude. High Alt Med Biol 2009;10(2):123-4.

21. Bärtsch P, Saltin B. General introduction to altitude adaptation and mountain sickness. Scand J Med Sci Sports 2008;18(S1):1-10.

22. Rusko HK, Tikkanen HO, Peltonen JE. Altitude and endurance training. J Sports Sci 2004;22:928-44.

23. Hoppeler H, Klossner S, Vogt M. Training in hypoxia and its effects on skeletal muscle tissue. Scand J Med Sci Sports 2008;18(S1):38-49.

24. Wilber RL, Stray-Gundersen J, Levine BD. Effect of hypoxic "dose" on physiological responses and sea-level performance. Med Sci Sports Exerc 2007;39(9):1590-9.

25. Gore CJ, Clark SA, Saunders PU. Nonhematological mechanisms of improved sea-level performance after hypoxic exposure. Med Sci Sports Exerc 2007;39(9):1600-9.

26. Beaver WL, Wasserman K, Whipp BJ. Bicarbonate buffering of lactic acid generated during exercise. J Appl Physiol 1986;60:472-8.

27. Green HJ, Roy B, Grant S, et al. Increases in submaximal cycling efficiency mediated by altitude acclimatization. J Appl Physiol 2000;89(3):1189-97.

28. Wehrlin JP, Halle'n J. Linear decrease in $\mathrm{VO}_{2 \max }$ and performance with increasing altitude in endurance athletes. Eur J Appl Physiol 2005;96:404-12.

29. Lundby C, Calbet JAL, van Hall G, et al. Pulmonary gas exchange at maximal exercise in Danish lowlanders during $8 \mathrm{wk}$ of acclimatisation to $4,100 \mathrm{~m}$ and in high altitude Aymara natives. Am J Physiol Regul Integr Comp Physiol. 2004;287(5): R1202-8.

30. Lundby C, Thomsen JJ, Boushel R, Koskolou M, Warberg J, Calbet JA, et al. Erythropoietin treatment elevates haemoglobin concentration by increasing red cell volume and depressing plasma volume. J Physiol 2007;578:309-14.

31. Schmidt W, Prommer N. Effects of various training modalities on blood volume. Scand J Med Sci Sports 2008;18(S1):59-71.

32. Levine BD, Stray-Gundersen J. "Living high-training low": effect of moderate altitude acclimatization with low altitude training on performance. J Appl Physiol 1997;83(1):102-12.

33. Friedmann B, Frese F, Menold E, Kauper F, Jost J, Bärtsch P. Individual variation in the erythropoietic response to altitude training in elite junior swimmers. Br J Sports Med 2005;39(3):148-53.

34. Heinicke K, Heinicke I, Schmidt W, Wolfarth B. A three-week traditional altitude training increases hemoglobin mass and red cell volume in elite biathlon athletes. Int J Sports Med 2005;26(5):350-5.

35. Gore CJ, Craig NP, Hahn A, Bourdon P, Lawrence S, Walsh C, et al. Altitude training at $2690 \mathrm{~m}$ does not increase total haemoglobin mass or sea level $\mathrm{VO}_{2 \max }$ in world champion track cyclists. J Sci Med Sport 1998;1(3):156-70. 
36. Gore CJ, Hahn AG, Burge CM, Telford RD. $\mathrm{VO}_{2 \max }$ and haemoglobin mass of trained athletes during high intensity training. Int J Sports Med 1997;18:477-82.

37. Chapman R, Levine BD. Altitude training for the marathon. Sports Med 2007;37(4-5):392-5.

38. Rodriguez FA, Ventura JL, Casas M, et al. Erythropoietin acute reaction and haematological adaptations to short, intermittent hypobaric hypoxia. Eur J Appl Physiol 2000;82:170-7.

39. Baar K. Training for endurance and strength: lessons from cell signaling. Med Sci Sports Exerc 2006;38:1939-44.

40. Hahn AG, Gore CJ. The effect of altitude on cycling performance: a challenge to traditional concepts. Sports Med 2001;31(7):533-57.

41. Brooks G, Butterfield GA, Wolfe RR, Groves BM, Mazzeo RS, Sutton JR et al. Increased dependence on blood glucose after acclimatization to $4300 \mathrm{~m}$. J Appl Physiol 1991;70(2):919-27.

42. Semenza GL. 02-regulated gene expression: transcriptional control of cardiorespiratory physiology by HIF-1. J. Appl.Physiol 2004;96:1173-7.

43. Sasaxi R, Masuda S, Nagao M. Erythropoietin: multiple physiological functions and regulation of biosynthesis. Biosci Biotechnol Biochem 2000;64:1775-93.

44. Vogt M, A. Puntschart A, Geiser J, Zuleger C, Billeter R, Hoppeler H. Molecular adaptations in human skeletal muscle to endurance training under simulated hypoxic conditions. J Appl Physiol 2001;91:173-82.

45. Melissa L, MacDougall JD, Tarnopolsky MA, et al. Skeletal muscle adaptations to training under normobaric hypoxic versus normoxic conditions. Med Sci Sports Exerc 1997;29:238-43.

46. Geiser J, Vogt M, Billeter R, Zuleger C, Belforti F, Hoppeler H. Training high-living low: changes of aerobic performance and muscle structure with training at simulated altitude. Int J Sports Med 2001;22:579-85.

47. Terrados N, Melichna J, Sylvén C, Jansson E, Kaijser L. Effects of training at simulated altitude on performance and muscle metabolic capacity in competitive road cyclists. Eur J Appl Physiol Occup Physiol 1988;57:203-9.

48. Stray-Gundersen J, Levine BD, Bertocci LA. Effect of altitude training on runner's skeletal muscle. Med Sci Sports Exerc 1999;31(5):S182

49. Wilber RL. Altitude training and athletic performance. Human Kinetics. 2004:13-4

50. Mizuno M, Juel C, Bro-Rasmussen T, Mygind E, Schibye B, Rasmussen B, et al. Limb skeletal muscle adaptation in athletes after training at altitude. J Appl Physiol 1990;68(2):496-502.

51. Saltin B, Kim CK, Terrados N, Larsen H, Svedenhag J, Rolf CJ. et al. Morphology, enzyme activities and buffer capacity in leg muscles of Kenyan and Scandinavian runners. Scand J Med Sci Sports 1995;5:222-30.

52. Gore CJ, Hahn AG, Aughey RJ, Martin DT, Ashenden MJ, Clark SA, et al. Live high: train low increases muscle buffer capacity and submaximal cycling efficiency. Acta Physiol Scand 2001;173:275-86.

53. Terrados N, Melichna J, Sylven C, Jansson E et al. Decrease in skeletal muscle myoglobin with intensive training in man. Acta Physiol Scand 1986;128(4):651-2.

54. Terrados N, Jansson E, Sylven C, Kaijser L. Is hypoxia a stimulus for synthesis of oxidative enzymes and myoglobin? J Appl Physiol 1990;68:2369-72.

55. Hoppeler H, Vogt M. Muscle tissue adaptations to hypoxia. J Exp Biol 2001;204(18):3133-9.

56. Jensen K, Nielsen JK, Fiskestrand A, Lund JO, Christensen NJ, Sechef NH. High-altitude training does not increase maximal oxygen uptake or work capacity at sea level in rowers. Scand J Med Sci Sports 1993;3:256-62. 
57. Bailey DM, Davies B, Romer L,Castell L, Newsholme E, Gandy G. Implications of moderate altitude training for sea-level endurance in elite distance runners. Eur J Appl Physiol 1998;78:360-8.

58. Gore CJ, Hopkins WG. Counterpoint: positive effects of intermittent hypoxia (live high:train low) on exercise performance are not mediated primarily by augmented red cell volume. J Appl Physiol 2005;99(5):2055-7.

59. Bonetti DL, Hopkins WG. Sea-level exercise performance following adaptation to hypoxia: a metaanalysis. Sports Med 2009;39(2):107-27.

60. Armstrong N, Mc Manus AM. The elite young athlete. Medicine and sport science. Karger, 2011. p.106

61. Geiser J, Vogt M, Billeter R, et al. Training high-living low: changes of aerobic performance and muscle structure with training at simulated altitude. Int J Sports Med 2001;22(8):579-85.

62. Lecoultre V, Boss A, Tappy L, Borrani F, Tran C, Schneiter P, et al. Training in hypoxia fails to further enhance endurance performance and lactate clearance in well-trained men and impairs glucose metabolism during prolonged exercise. Exp Physiol 2010;95(2):315-30.

63. Roels B, Bentley DJ, Coste O, Mercier J, Millet GP. et al. Effects of intermittent hypoxic training on cycling performance in well-trained athletes. Eur J Appl Physiol 2007;101(3):359-68.

64. Debevec T, Amon M, Keramidas ME, Kounalakis SN, Pisot R, Mekjavic IB. Normoxic and hypoxic performance following 4 weeks of normobaric hypoxic training. Aviat Space Environ Med 2010;81(4):387-93.

65. Ventura N, Hoppeler H, Seiler R, Binggeli A, Mullis P, Vogt M. The response of trained athletes to six weeks of endurance training in hypoxia or normoxia. Int J Sports Med 2003;24(3):166-72.

66. Saunders PU, Ahlgrim C, Vallance B, Green DJ, Robertson EY, Clark SA, et al. An attempt to quantify the placebo effect from a three-week simulated altitude training camp in elite race walkers. Int J Sports Physiol Perform 2010;5(4):521-34.

67. Meeuwsen T, Hendriksen IJ, Holewijn M. Training induced increases in sea-level performance are enhanced by acute intermittent hypobaric hypoxia. Eur J Appl Physiol 2001;84(4):283-90.

68. Hamlin MJ, Marshall HC, Hellemans J, Ainslie PN, Anglem N. Effect of intermittent hypoxic training on $20 \mathrm{~km}$ time trial and $30 \mathrm{~s}$ anaerobic performance. Scand J Med Sci Sports 2010;20(4):651-61.

69. Morton JP, Cable NT. Effects of intermittent hypoxic training on aerobic and anaerobic performance. Ergonomics 2005;48(11-14):1535-46.

70. Gore CJ, Little SC, Hahn AG, Watson DB, Emonson DL. Reduced performance of male and female athletes at $580 \mathrm{~m}$ altitude. Eur J Appl Physiol 1997;75:136-143.

71. Calbet JA, Boushel R, Rådegran G, Søndergaard H, Wagner PD, Saltin B. Determinants of maximal oxygen uptake in severe acute hypoxia. Am J Physiol Regul Integr Comp Physiol 2003;284(2):R291-303.

72. Burtscher M, Nachbauer W, Baumgartl P, Philadelphy M. Benefits of training at moderate altitude versus sea level training in amateur runners. Eur J Appl Physiol 1996;74:558-63.

73. Gore CJ, Hahn AG, Burge CM, Telford RD. $\mathrm{VO}_{2 \max }$ and haemoglobin mass of trained athletes during high intensity training. Int J Sports Med 1997;18:477-82.

74. Strzała M, Ostrowski A, Szyguła Z. Altitude Training and its Influence on Physical Endurance in Swimmers. J Hum Kinet 2011;28:91-105.

75. Levine BD, Stray-Gundersen J, Duhaime G, et al. 'Living high-training low': the effect of altitude acclimatization/normoxic training in trained runners [abstract]. Med Sci Sports Exerc 1991;23:S25.

76. Millet GP, Roels B, Schmitt L, et al. Combining hypoxic methods for peak performance. Sports Med 2010;40(1):1-25.

77. Stray-Gundersen J, Chapman RF, Levine BD. "Living high - training low" altitude training improves sea level performance in male and female elite runners. J Appl Physiol 2001;91:1113-20.

Rev. Cienc. Salud. 12 (1): 107-122 / 121 
78. Wehrlin JP, Zuest P, Hallén J, Marti B. Live high-train low for 24 days increases hemoglobin mass and red cell volume in elite endurance athletes. J Appl Physiol 2006;100:1938-45.

79. Dehnert C, Hutler M, Liu Y, Menold E, Netzer C, Schick R. Erythropoiesis and performance after two weeks of living high and training low in well trained triathletes. Int J Sports Med 2002;23(8):561-6.

80. Richalet JP, Gore CJ. Live and/or sleep high-train low, using normobaric hypoxia. Scand J Med Sci Sports 2008;18(S1):29-37.

81. Hahn AG, Gore CJ, Martin DT, Ashenden MJ, Roberts AD, Logan PA. An evaluation of the concept of living at moderate altitude and training at sea level. Comp Biochem Physiol A Mol Integr Physiol 2001;128(4):777-89.

82. Truijens MJ, Rodríguez FA, Townsend NE, Stray-Gundersen J, Gore CJ, Levine BD. The effect of intermittent hypobaric hypoxic exposure and sea level training on submaximal economy in well-trained swimmers and runners. J Appl Physiol 2008;104(2):328-37.

83. Hellemans J. Intermittent hypoxic training: a pilot study. Proceedings of the Second Annual International Altitude Training Symposium. 1999 Feb:18-20. Available on:http://fulltext.ausport.gov.au/ fulltext/1999/triathlon/john.hellemans3.pdf Accessed on January 152012.

84. Julian CG, Gore CJ, Wilber RL, Daniels JT, Fredericson M, Stray-Gundersen J, et al. Intermittent normobaric hypoxia does not alter performance or erythropoietic markers in highly trained distance runners. J Appl Physiol 2004;96(5):1800-7.

85. Czuba M, Waskiewicz Z, Zajac A, Poprzecki S, Cholewa J, Roczniok R. The effects of intermittent hypoxic training on aerobic capacity and endurance performance in cyclists. J Sports Sci Med 2011;10:175-83.

86. Truijens MJ, Toussaint HM, Dow J, Levine BD. Effect of high-intensity hypoxic training on sea-level swimming performances. J Appl Physiol 2003;94(2):733-43.

87. Vallier JM, Chateau P, Guezennec CY. Effects of physical training in a hypobaric chamber on the physical performance of competitive triathletes. Eur J Appl Physiol Occup Physiol 1996;73(5):471-8. 